ABDIMAS: Jurnal Pengabdian Masyarakat Universitas Merdeka Malang
Vol.6(3) August 2021, 372-383
i-ISSN: 2721-138X e-ISSN: 2548-7159
Uttp://jurnal.unmer.ac.id/index.php/jpkm

\title{
Pemanfaatan Bio-Economy dari Glycine Max dan Digital Marketing bagi Pengrajin Tempe
}

\author{
Siti Komariyah, Lilis Yuliati, Riniati Riniati \\ Departemen Ekonomi Pembangunan, Fakultas Ekonomi dan Bisnis, Universitas Jember \\ Jl. Kalimantan No.37 Jember, 68121, Indonesia
}

\begin{abstract}
ARTICLE INFO
Received: 2020-12-23

Revised: 2021-02-10

Accepted: 2021-04-07

Keywords:

Creativity, Innovation, Marketing

ABSTRACT

One of the potentials Jambearum village is from the tempe production which is located in Puger, Jember regency. This potential has the opportunity to be developed into a center for SMEs, because several businesses have joined the "Paguyuban Delima" with the aim of building a forum for communication, friendship, besides a forum for activities to strengthen family functions in an integrated manner, through economically beneficial efforts. However, this potential is constrained by several fundamental problems, including human resources, limited creativity and innovation, marketing, and capital. Aims this research to create innovation of tempeh chips and marketing. To develop business, direct action method through practice is carried out with socialization steps to foster aspects of innovation and creativity. Then marketing is carried out by socialization and introduction to social media methods, sealer and brand design to market standards while reaching a wider and easier market. The method for capital problems is done by providing direct assistance in the form of a tempe cutting machine. Result shows that a new innovation from tempe products to increase the selling value with the innovation of tempe chip products with various flavors that are packaged and branded in such a way as to attract consumers.
\end{abstract}

(C)2021 Published by University of Merdeka Malang. This is an open access article distributed under the CC BY-SA 4.0 license (https://creativecommons.org/licenses/by-sa/4.0/)

How to cite: Komariyah, S., Yuliati, L., \& Riniati, R. (2021). Pemanfaatan Bio-Economy dari Glycine Max dan Digital Marketing bagi Pengrajin Tempe. Abdimas: Jurnal Pengabdian Masyarakat Universitas Merdeka Malang, 6(3), 372-383. https://doi.org/10.26905/abdimas.v6i3.5197

\section{PENDAHULUAN}

Desa Jambearum merupakan salah satu desa yang terletak di Kecamatan Puger, Kabupaten Jember. Jarak desa ini dari pusat kota kurang lebih 28,4 Km (BPS, 2017). Dari tiga dusun yang terletak di Desa Jambearum yaitu, Dusun Darungan, Krajan, dan Kedungsumur. Dusun Krajan merupakan dusun yang memiliki potensi dan berpeluang untuk dikembangkan menjadi sentra UMKM, karena banyak penduduknya memiliki usaha kecil sebagai pengrajin tempe yang tergabung dalam "Paguyuban Delima" yang bertujuan untuk membangun forum komunikasi, silaturahmi, sekaligus sebagai wadah kegiatan 
penguatan fungsi keluarga secara terpadu, melalui usaha-usaha yang bermanfaat secara ekonomis (BPS, 2017). Beberapa permasalahan yang terjadi dalam industri kecil tempe di wilayah ini dikarenakan kurangnya diferensiasi dan diversifikasi dari olahan produk tempe itu sendiri serta minimnya pemasaran baik secara manual maupun digital. Di tengah gencarnya era digital saat ini, inovasi harus lebih diasah untuk memperoleh produk-produk baru yang memiliki nilai jual dan value added yang lebih tinggi dan mampu berdaya saing. Hal ini juga didukung dengan pengelolaan pemasaran yang dapat dijangkau lebih luas lagi melalui teknologi seperti pemasaran secara digital melalui media sosial (Uula et al., 2019).

Diversifikasi dan diferensiasi produk ini merupakan salah satu strategi pemasaran suatu produk yang memiliki kemampuan untuk dikembangkan lebih luas. Pada dasarnya, strategi ini mengarah pada hasil produk yang lebih efektif, efisien, dan memiliki pembeda dari produk lain serta dapat menempati segmen pasar yang lebih baik (Gregorius, 2010). Diversifikasi produk diartikan sebagai pemahaman subjektif dari produsen atas suatu produk yang ditawarkan untuk mencapai tujuan industri yang ditujukan untuk menarik daya beli konsumen di pasar (Jayathilake 2018). Sementara menurut Adamu et al. (2011) dan Scur \& De Queiroz (2017), diversifikasi produk merupakan suatu upaya industri atau produsen untuk menganekaragamkan produknya baik dalam bentuk sifat maupun fisik dari barang atau jasa yang dihasilkan untuk tujuan memuaskan kebutuhan konsumen. Diversifikasi produk dengan melakukan inovasi-inovasi baru disesuaikan dengan permintaan pasar untuk meningkatkan dan mempertahankan daya saing di pasarnya (Suharno \& Saraswati, 2019; Tarida, 2018). Hal ini dapat menjadi faktor pendorong dari peningkatan volume penjualan dan memperluas segmentasi pasar dengan berbagai inovasi yang dimunculkan. Strategi ini dimungkinkan akan memiliki implikasi yang kompleks untuk pengembangan produk dan perluasan pasar. Selain itu, strategi diversifikasi juga menjadi alternatif peningkatan penjualan dan pengembangan dengan produk yang berbeda. Berbeda dengan diversifikasi, strategi diferensiasi produksi ini dilakukan oleh produsen menekankan pada pengembangan dalam menghasilkan produk yang lebih unik dan berbeda sehingga dapat menjadi daya tarik konsumen untuk mengkonsumsi produk tersebut (Tarida, 2018). Pada strategi ini, produsen lebih berfokus pada pengembangan jenis produk dan berpotensi menjadi daya tarik konsumen lebih tinggi sehingga perusahaan berpeluang memiliki keuntungan yang lebih besar. Pemasaran digital ini menjadi alternatif yang saat ini signifikan dalam meningkatkan dan memperluas pemasaran bagi usaha kecil dan menengah (UKM). Penggunaan media sosial seperti Facebook, Twitter, Instagram, dan website lainnya menjadi alternatif yang dianggap efisien untuk menjangkau segmen pasar yang lebih luas lagi (Tahwi, 2020; Wardhana, 2015).

Selain permasalahan pemasaran, dengan potensi besar yang dimiliki oleh Dusun Krajan tersebut tidak diimbangi oleh skill dari sumber daya manusianya. Berdasarkan hasil survei dan wawancara yang dilakukan oleh tim Pengusul PPK, ternyata permasalahan yang terjadi, antara lain: (1) Kurangnya kreativitas dan tidak adanya derivate product mengakibatkan perkembangan usaha tempe ini kurang maksimal; (2) Kurang memadainya sarana yang digunakan dalam proses produksi; (3) Terbatasnya wilayah pemasaran tempe, yang hanya dipasarkan di sekitar desa tersebut; (4) Kurang efektifnya proses pembuatan tempe yang membutuhkan waktu lama tidak sebanding dengan output yang dihasilkan. Proses pengolahan tempe dari tahapan awal hingga akhir memerlukan waktu hingga hampir $12 \mathrm{jam}$. Hal ini menjadikan efektivitas dan efisiensi tidak sebanding dengan hasil yang diperoleh oleh pelaku jika tempe mengalami masalah seperti tidak matang maksimal maupun tidak laku. Oleh karena itu, solusi yang dapat dilakukan 
ABDIMAS: Jurnal Pengabdian Masyarakat Universitas Merdeka Malang Volume 6, No. 3, August 2021: 372-383

dengan cara melakukan inovasi dengan pengolahan keripik tempe yang memiliki nilai jual lebih tinggi serta tidak mudah busuk seperti tempe mentah sebelum diolah (Kurniawati, 2016).
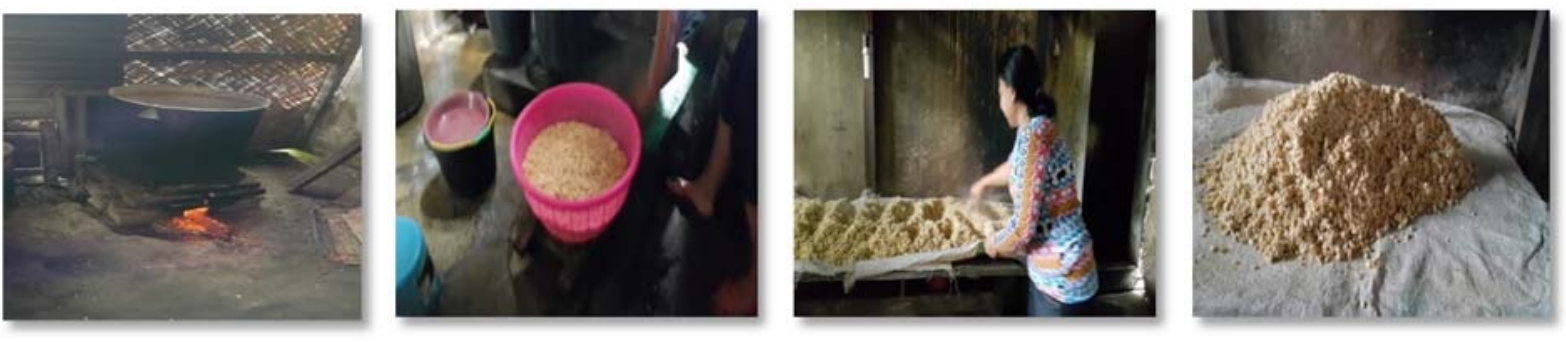

Gambar 1. Proses produksi tempe

Dalam proses pengolahan tempe, terdapat tahapan peragian yang menjadi salah satu tahapan dengan resiko cukup besar. Hal ini terjadi karena jika peragian dilakukan pada cuaca terlalu panas juga akan memengaruhi hasil tempe. Cuaca yang tidak menentu mengakibatkan hasil peragian kurang maksimal sehingga tempe akan cepat busuk. Kondisi cuaca membawa pengaruh cukup signifikan terhadap hasil olahan tempe. Ini juga menjadi faktor penentu untung rugi pelaku usaha tempe sebab pembuatan tempe yang memakan waktu cukup lama seharusnya sebanding dengan nilai jualnya karena tempe hari ini, dijual untuk waktu 2 hari yang akan datang. Begitu seterusnya siklus produksi tempe.

Selain resiko cuaca, resiko tempe tidak habis terjual merupakan pemandangan yang hampir setiap hari terjadi. Selama ini pengusaha tempe rumahan menjual hasil produksinya hanya di pasar di Jambearum dan dititipkan pada pedagang sayur keliling. Jika ada tempe yang tidak habis terjual, pengusaha tempe akan menjual tempe dengan harga murah agar kerugian yang diderita tidak terlalu besar dan sisa tempe yang tidak terjual dapat dibeli meskipun dengan harga murah. Jika ditinjau besaran biaya produksi yang dikeluarkan setiap satu kali produksi rata-rata sebesar Rp150.000,- dengan penghasilan rata-rata setiap hari Rp200.000,- dan tingkat keuntungan kotor rata-rata sebesar Rp50.000,- dengan asumsi semua tempe laku terjual dengan harga normal. Namun jika ada tempe yang tidak laku, kentungan menjadi lebih kecil bahkan kadangkala hasil penjualan dibayarkan tidak penuh oleh penjual eceran.

Keuntungan yang diperoleh setiap hari yang diterima pengusaha tempe tidak memasukkan pengeluaran biaya tenaga kerja, karena mereka berprinsip tenaga mereka tidak perlu dibayar karena dikerjakan sendiri oleh ibu rumah tangga atau keluarga (implisit cost). Proses pengolahan tempe yang dikelola dengan manajemen yang sederhana, modal dan daerah pemasaran yang terbatas di lingkungan tempat tinggal, dan tidak adanya derivate olahan produk berbahan dasar kedelai yang mudah busuk menjadi masalah utama. Kurangnya derivate produk ini juga mengakibatkan nilai jual tempe sangat rendah ketika tempe tidak terjual karena busuk.

Berdasarkan permasalahan tersebut, diperlukan solusi yang dapat memberikan kontribusi yang positif bagi pengrajin tempe baik dari sisi produksi, pemasaran, maupun inovasi untuk meningkatkan nilai jual dan value added dari tempe tersebut salah satunya melalui inovasi produk keripik tempe. Beberapa permasalah yang dihadapi mitra antara lain, kreativitas yang masih minim, keterbatasan tempe yang mudah busuk dan hanya mampu bertahan satu hari, belum terdapat brand, perlunya derivasi produk dari tempe kedelai agar mendapat nilai tambah dan nilai jual yang lebih tinggi dengan variasi rasa sesuai 
selera pasar, keterbatasan modal dan pengetahuan baik untuk produksi maupun berwirausaha (Kotler, 2012; Oentoro, 2010).

Target luaran praktis yang diharapkan menjadi solusi bagi mitra dalam kegiatan ini antara lain menciptakan inovasi derivation produk berupa keripik tempe aneka rasa dengan gizi tinggi, tahan lama, dan memiliki nilai tambah serta daya jual tinggi. Peningkatan produktivitas dan pendapatan pengrajin tempe di Paguyuban Delima Jambearum. Lebih lanjut, perlu adanya branding produk dengan didukung kemasan yang rapi dan marketable serta dukungan peralatan usaha yang layak.

\section{METODE}

Kegiatan ini dilakukan di Desa Jambearum, Kecamatan Puger, Kabupaten Jember tepatnya di Dusun Krajan dengan mitra yang terlibat dari pelaku usaha tempe. Terdapat dua mitra yang terlibat dalam kegiatan ini yang tergabung dalam anggota "Paguyuban Delima". Dua mitra sebagai pelaku usaha tempe tersebut adalah Azis Solihin yang beralamat di Dusun Krajan, RT.02/RW.05, Jambearum dan Sutrisno yang terletak di Dusun Krajan, RT.01/RW.02 Jambearum. Beberapa metode yang digunakan untuk melaksanakan kegiatan ini sesuai tujuan kegiatan: (1) Pemberian pelatihan teknis pembuatan keripik tempe aneka rasa dengan standar tertentu sehingga ukuran dan ketebalan keripik tempe sama sekaligus cara pemrosesan yang higienis. Pada langkah ini diberikan alat produksi seperti alat penggorengan dan alat pemotong tempe dengan tujuan hasil pemotongan dapat lebih rapi dan memiliki ketebalan serta ukuran yang sama; (2) Pemberian pelatihan teknis proses pengemasan yang baik dan sesuai standar pasar sehingga dapat menjaga kerenyahan dalam jangka waktu hingga 6 bulan tanpa bahan pengawet; (3) Mengarahkan dan memberikan pengetahuan tentang cara memasarkan hasil produk keripik tempe di lingkungan Desa Jambearum dan seluruh desa di Kecamatan Puger hingga bisa mencapai seluruh wilayah Kabupaten Jember dengan memanfaatkan media sosial.
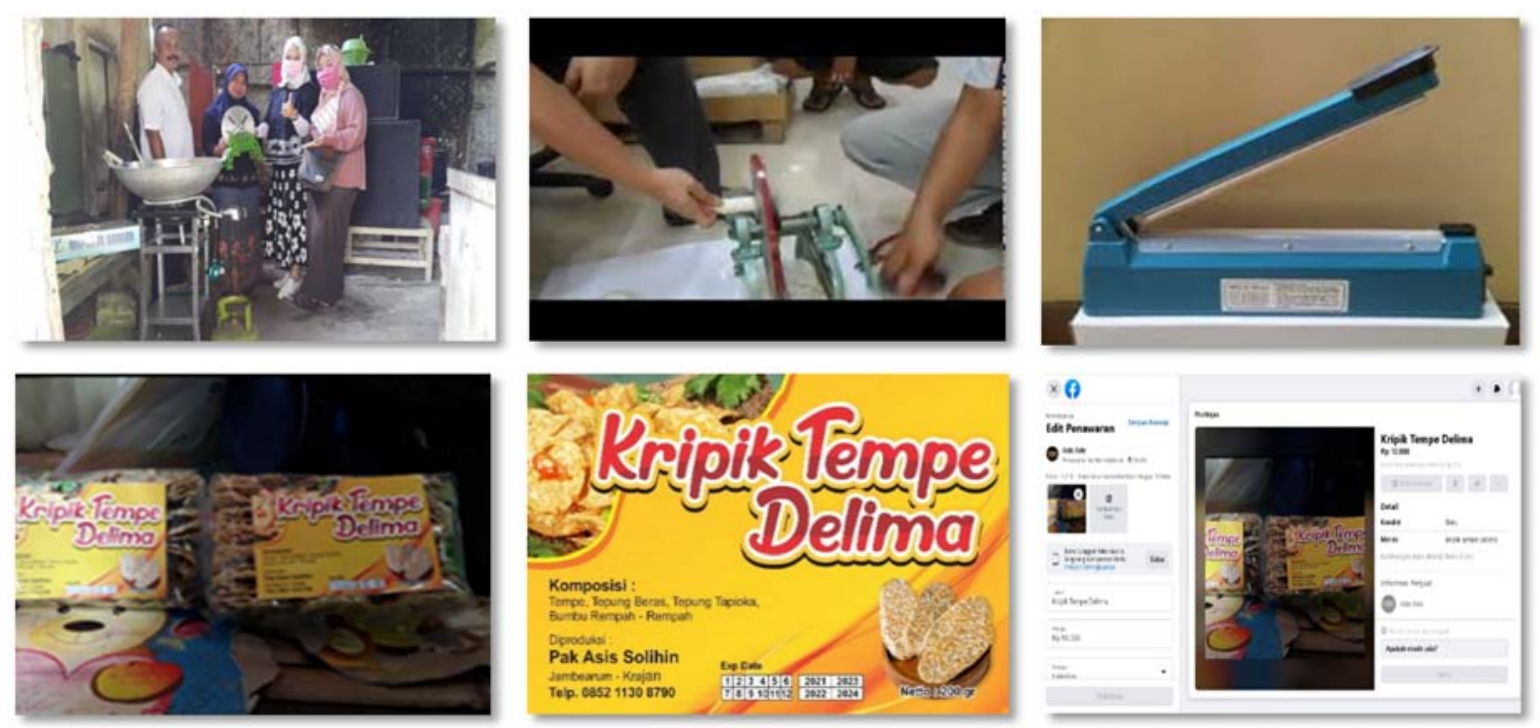

Gambar 2. Pemberian alat produksi

Gambar 3. Proses pelatihan teknis pengemasan

Gambar 4. Bentuk pemasaran digital 
ABDIMAS: Jurnal Pengabdian Masyarakat Universitas Merdeka Malang Volume 6, No. 3, August 2021: 372-383

Adanya permintaan yang besar pada produk makanan ringan yang enak dan sehat, memotivasi Tim PPK untuk memfasilitasi mitra untuk melakukan proses derivate product. Tindakan ini dilakukan dengan cara mengolah tempe menjadi keripik dengan aneka rasa, sehingga terdapat alternatif pilihan bagi penikmat makanan dan camilan enak dan sehat. Selain itu, derivate product ini menjadi pilihan utama bagi mitra pengrajin tempe sebagai upaya pengembangan usaha dengan diversifikasi produk tempe yang lebih variatif. Upaya ini diwujudkan dalam bentuk keripik yang dapat memberikan nilai jual dan value added lebih besar sekaligus membuka peluang usaha untuk lebih memperluas jaringan pasar. Kegiatan ini juga dapat menjadi pendukung dalam rangka menjalankan program Paguyuban Delima di bidang pengembangan ekonomi secara mandiri. Dalam proses produksi keripik tempe ini yang perlu ditekankan adalah kualitas dari hasil produksinya. Keripik tempe yang berkualitas adalah keripik yang enak, sehat, bebas kolestrol, dan bebas bahan pengawet serta tentunya keripik tempe yang bersih dan higienis. Dengan mengedepankan kebersihan pada saat proses produksi hingga proses pengemasan, akan memberikan rasa aman bagi konsumen. Selain itu, bahan baku yang baik juga sangat menentukan kualitas keripik tempe ini. Adapun yang akan digunakan sebagai bahan baku pembuatan keripik tempe ini adalah bahan baku tempe yang paling baik kualitasnya sehingga akan menghasilkan keripik dengan kualitas yang baik juga. Selain itu, pemasaran juga menjadi hal yang urgent untuk diperhatikan dalam pengelolaan industri ini (Febrini et al., 2019; Soemali \& Dharmayanti, 2015). Gambar 5 menunjukkan peta lokasi kegiatan yang terletak di Dusun Krajan, Desa Jambearum, Kecamatan Puger, Kabupaten Jember.

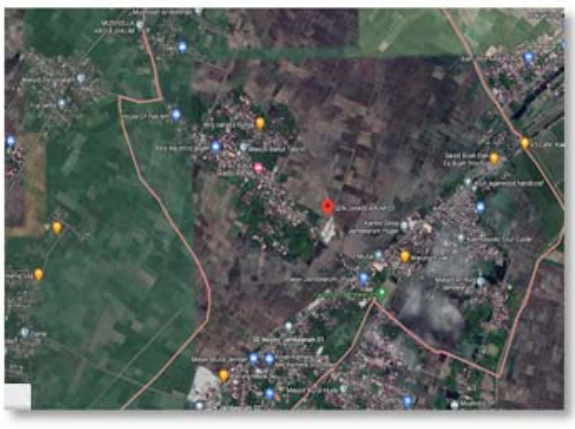

Gambar 5. Peta lokasi kegiatan

\section{HASIL DAN PEMBAHASAN}

\section{Strategi dalam diversifikasi dan diferensiasi produk tempe dengan melakukan inovasi pengolahan produk keripik tempe}

Pada mulanya, hasil produksi tempe hanya berupa tempe mentah yang kemudian dipasarkan di pasar sekitar Jambearum dan Puger. Inovasi ini muncul untuk mengatasi permasalahan nilai jual yang masih rendah sehingga perlu adanya variasi produk melalui diversifikasi produk yang dihasilkan dari produk turunan berbahan dasar tempe yaitu keripik tempe. Di beberapa daerah, keripik tempe dijadikan sebagai oleh-oleh khas daerah sehingga memiliki nilai jual lebih tinggi dibandingkan dengan tempe mentah biasa yang dijadikan sebagai kebutuhan lauk pauk sehari-hari. Keberadaan hasil produksi keripik tempe ini diharapkan dapat menjadi solusi untuk meningkatkan nilai jual tempe sekaligus dapat memberikan dampak untuk meningkatkan pendapatan pelaku usaha. 
Strategi ini bertujuan untuk meningkatkan daya saing serta nilai jual produk dengan penganekaragaman melalui inovasi dan diferensiasi dari produk tempe menjadi keripik tempe yang diharapkan akan memiliki daya tarik lebih besar di pasar. Proses pengolahan keripik tempe di Desa Jambearum, Kecamatan Puger, Kabupaten Jember ini melalui beberapa tahapan dan beberapa komposisi bahan yang mendukung. Beberapa bahan yang digunakan dalam pengolahan keripik tempe tersebut antara lain: (1) $250 \mathrm{gr}$ tepung beras (setara dengan $15 \mathrm{sdm}$ ); (2) $125 \mathrm{gr}$ tepung tapioka (setara dengan $7 \mathrm{sdm}$ ); (3) 2 buah tempe super (dengan tekstur yang padat) ukuran tempe antara 500-600 gr; (4) 1 butir telur (gunakan putih dan kuning telur); (5) 1 bungkus penyedap rasa atau kaldu (sesuai selera); (6) Air sekitar 300-350 ml; (7) Minyak goreng secukupnya (kurang lebih $500 \mathrm{ml}$ ); (8) Bumbu halus yang terdiri dari: (a) 4 siung bawang putih; (b) 1 sdt ketumbar halus (sesuai selera); (c) 1 ruas kunyit; (d) 2-3 buah kemiri; (e) Garam 2 sdt; (9) Daun jeruk purut sebagai tambahan penyedap rasa.

Komposisi bahan di atas merupakan komponen bahan untuk membuat keripik tempe yang kemudian diolah sesuai dengan tahapan pembuatan. Beberapa fungsi dari bahan-bahan di atas memberikan manfaat yang berbeda dan dapat memberikan rasa yang enak dan sedap. Daun jeruk purut disini berfungsi sebagai penambah penyedap rasa pada keripik tempe sehingga tempe dapat lebih gurih dan renyah dengan potongan tipis daun jeruk yang dimasukkan di adonan nantinya. Kemudian, kunyit berguna untuk memberikan warna pada adonan sehingga nantinya hasil dari gorengan keripik yang sudah matang dapat memberikan warna yang cantik dan menarik.

Bahan utama dari pembuatan keripik tempe ini berasal dari tempe yang diolah langsung oleh warga Desa Jambearum, Kecamatan Puger. Tempe yang digunakan adalah tempe yang bertekstur padat sehingga ketika dipotong akan menghasilkan hasil yang rapi dan mudah diaplikasikan di adonan yang telah dibuat. Melalui upaya ini, tempe tidak hanya sebagai bahan dasar lauk pauk saja, namun juga dapat memiliki nilai tambah dan nilai jual lebih tinggi sebagai bahan cemilan maupun oleh-oleh yang berkualitas dan memenuhi standar pasar. Komposisi dari bahan-bahan tersebut kemudian diolah dengan melalui beberapa tahapan sebagai berikut: (1) Tahap awal siapkan semua bahan seperti yang telah ditunjukkan, kemudian pertama potong tempe dengan pisau atau alat pemotong sehingga hasilnya lebih rapi. Pada tahapan pertama ini, disiapkan tempe yang sudah jadi dengan tekstur yang padat sehingga ketika nanti dipotong tidak rusak dan tetap rapi. Kemudian tempe mulai dimasukkan ke pisau pemotong untuk selanjutnya dilakukan pemotongan sesuai selera. Rata-rata pemotongan dilakukan dengan mengatur pisau pemotong supaya hasil potongan lebih tipis dan rapi ketika dimasukkan dalam tepung dan digoreng akan lebih renyah (Gambar 6); (2) Potong halus daun jeruk untuk selanjutnya dimasukkan pada adonan tepung nanti (Gambar 7). Potong daun jeruk hingga tipis dan rapi sebagai tambahan penyedap rasa sekaligus sebagai penambah warna sehingga hasil gorengan terlihat lebih menarik. Selain itu, daun jeruk juga dapat menambah wangi pada keripik lebih segar dan tahan lama dalam waktu beberapa hari; (3) Haluskan semua bumbu seperti bawang putih, ketumbar, kunyit disertai dengan garam (Gambar 8). Beberapa bumbu yang sudah dimasukkan antara lain terdiri dari 4 siung bawang putih, 1 sendok teh ketumbar, 1 ruas kunyit, 2-3 kemiri dan garam 2 sendok teh. Bumbu kemudian dihaluskan hingga halus sebelum kemudian dimasukkan dalam adonan yang sudah dicampur dengan tepung. 
ABDIMAS: Jurnal Pengabdian Masyarakat Universitas Merdeka Malang Volume 6, No. 3, August 2021: 372-383
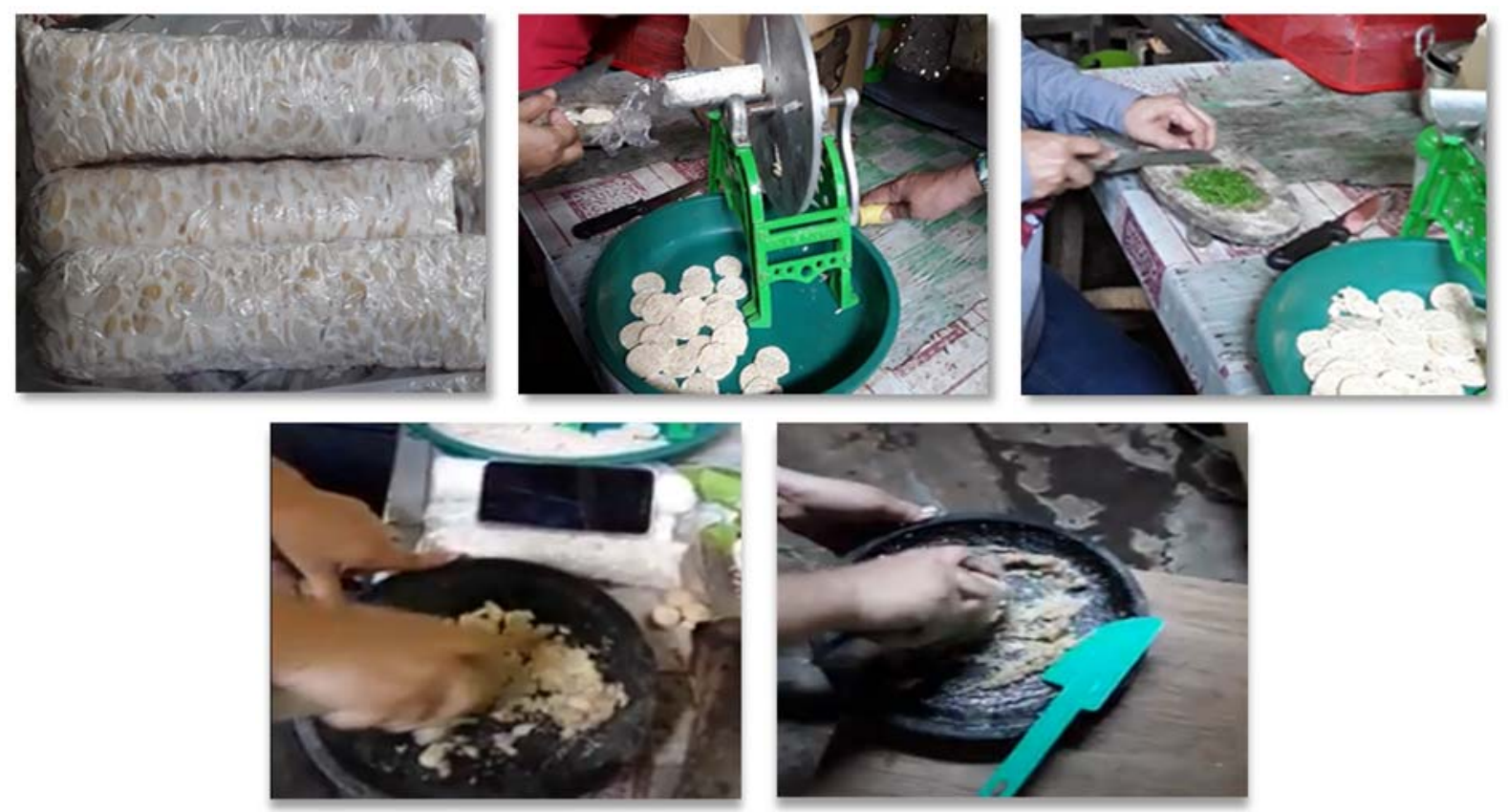

Gambar 6. Tempe yang dipotong dengan alat pemotong

Gambar 7. Potong daun jeruk purut

Gambar 8. Bumbu yang sudah dihaluskan

Proses selanjutnya yaitu: (4) Siapkan wadah dan masukkan tepung beras, tepung tapioka, telur, dan bumbu halus. Pada tahapan ini, akan dicampurkan bahan-bahan kering untuk adonan seperti tepung beras dan tepung tapioka kemudian dicampur dengan telur dan bumbu halus (Gambar 9). Pada tahapan ini, digunakan tepung sesuai resep yaitu sebanyak $1 \mathrm{sdm}$ (sendok makan) atau sebesar 250 gr tepung beras, $7 \mathrm{sdm}$ tepung tapioka atau sebesar $125 \mathrm{gr}$, satu buah telur utuh (putih dan kuning telur). Pertama, masukkan bahan kering yang terdiri dari tepung beras, tepung tapioka, garam dan penyedap rasa sesuai selera. Kemudian aduk hingga rata. Setelah itu masukkan telur utuh dan bumbu halus dan campur dengan cara mengaduk hingga rata; (5) Masukkan air dan daun jeruk purut pada wadah bahan adonan (Gambar 10). Tahapan ini dilakukan untuk mencampur bahan setengah kering tadi untuk selanjutnya dicampur dengan air secukupnya. Penuangan dilakukan sedikit demi sedikit air ke dalam adonan sehingga dapat mengukur kekentalan dan tekstur adonan yang sesuai digunakan nantinya. Adonan yang baik dapat dilihat ketika bahan sudah tercampur kemudian dapat dicek dengan melihat tekstur kekentalannya. Adonan yang baik adalah adonan yang tidak terlalu kental dan tidak terlalu encer. Adonan yang terlalu encer akan cenderung merusak bentuk lapisan keripik itu sendiri serta bisa jadi tidak melekat dengan maksimal di tempe ketika dicampur sehingga ketika digoreng hasilnya kurang maksimal. Kemudian setelah adonan dirasa sudah sesuai, maka dapat dicampur dengan irisan atau potongan daun jeruk purut yang dipotong halus kemudian diaduk kembali hingga merata. Tujuan dari penggunaan daun jeruk ini untuk lebih mempercantik penampilan sekaligus menambah aroma dan rasa lebih gurih dan sedap pada hasil gorengan keripiknya nanti. 

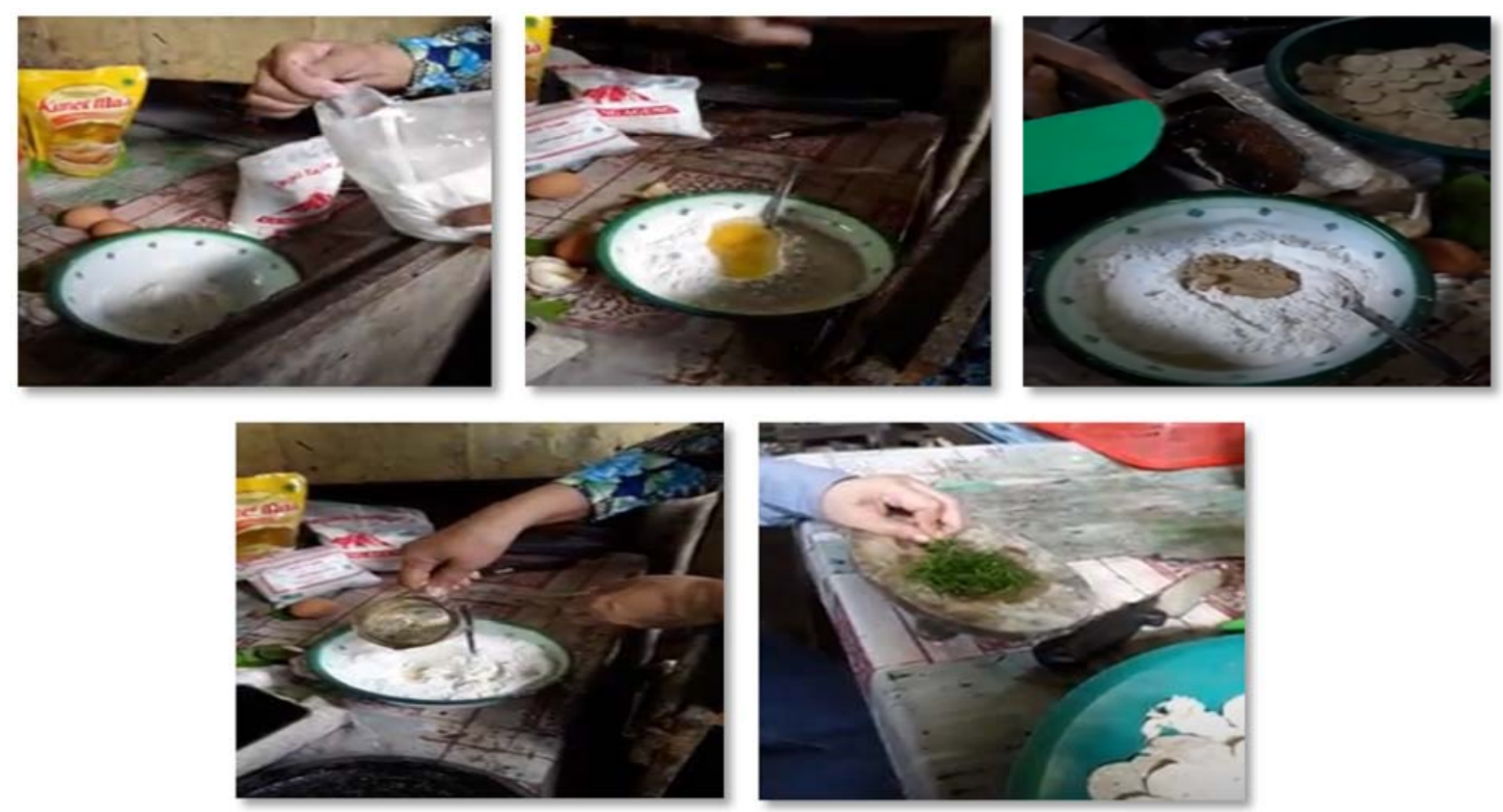

Gambar 9. Pencampuran tepung adonan dan bumbu halus

Gambar 10. Penuangan air dan daun jeruk purut ke adonan

Tahap selanjutnya yaitu: (6) Pencampuran adonan dengan tempe yang sudah diiris tipis hingga merata semua keseluruh irisan tempe agar hasilnya rapi dan renyah dan penuangan minyak dalam wadah penggorengan (Gambar 11). Pada tahapan ini, ketika tekstur adonan sudah baik dan sudah tercampur rata dengan daun jeruk dan bumbu halus, maka irisan tempe selanjutnya dimasukkan dan dicampur hingga seluruh lapisan tempe dapat tertutup dengan adonan tepung. Hal ini dilakukan agar hasil penggorengan merata dan renyah. Kemudian dituangkan minyak goreng secukupnya pada wajan penggorengan yang sudah panas dengan api sedang dan ditunggu minyak hingga menunjukkan tandatanda panas agar nanti ketika adonan dan tempe dimasukkan dapat bereaksi langsung dengan baik. Waktu menunggu minyak hingga panas membutuh waktu sekitar 3-5 menit; (7) Masukkan tempe yang telah dicampur ke adonan kedalam minyak panas (Gambar 12). Minyak yang sudah panas dalam wajan penggorengan siap untuk dimasuki adonan tempe. Kemudian setelah dimasukkan semua satu per satu dapat diaduk sehingga tempe tidak bergabung dan menumpuk satu sama lain. Setelah beberapa detik dimasukkan ke dalam penggorengan sebaiknya tempe langsung dipisah jika ada yang menempel satu dengan yang lain sebelum adonan mengeras dan susah untuk dipisahkan; (8) Angkat tempe ketika sudah mulai menguning matang (Gambar 13). Ini membutuhkan waktu kurang lebih sekitar 5-7 menit agar tempe matang dengan merata. Selain itu, pada tahap ini juga perlu untuk sering mengaduk sehingga setiap sisi dari hasil gorengan dapat matang secara merata dan baik; (9) Setelah itu, hasil gorengan keripik tempe ditiriskan terlebih dahulu beberapa menit hingga dingin sebelum nantinya dikemas ke dalam packing yang telah disediakan. 
ABDIMAS: Jurnal Pengabdian Masyarakat Universitas Merdeka Malang Volume 6, No. 3, August 2021: 372-383
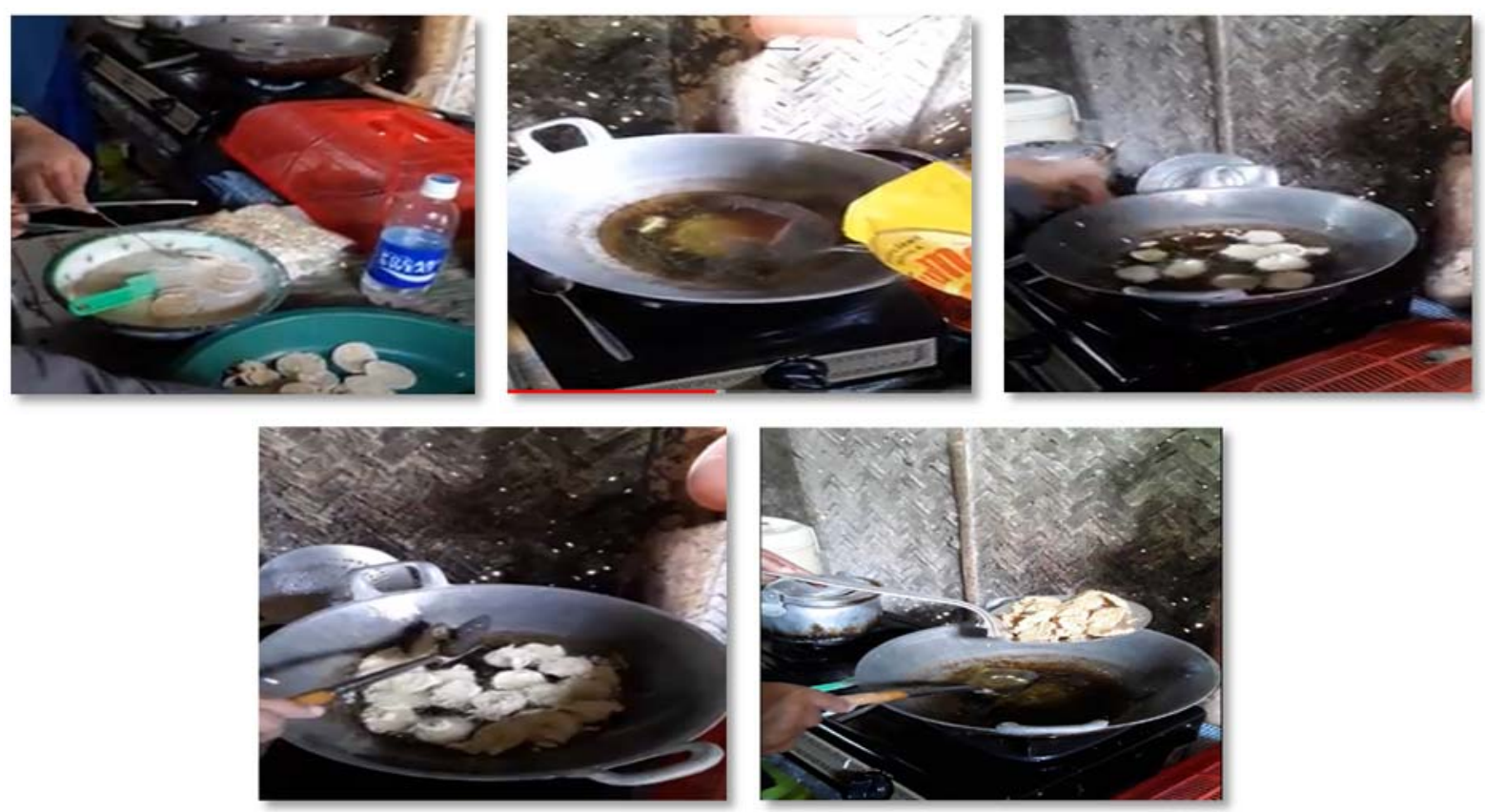

Gambar 11. Campur adonan dengan irisan tempe dan penuangan minyak Gambar 12. Adonan dan tempe yang dicampur dimasukkan ke penggorengan

Gambar 13. Keripik tempe diangkat dari penggorengan

\section{Proses pengemasan dan pemasangan brand produk}

Untuk mencapai tujuan agar produk mampu berdaya saing di pasaran dan sesuai dengan permintaan pasar, maka diperlukan suatu branding dan pengemasan yang rapi sehingga dapat menarik minat konsumen. Pengemasan dilakukan dengan menggunakan plastik sesuai dengan standar pasar dengan tingkat ketebalan tertentu untuk meminimalisir adanya kerusakan produk dan agar produk lebih awet dengan packaging yang rapi. Kemudian diberikan brand yang berisi merk sesuai dengan nama paguyuban yaitu "Kripik Tempe Delima" yang didesain menarik sekaligus dicantumkan komposisi, dan tanggal kadalursa agar pembeli tidak ragu dengan kualitas produk.
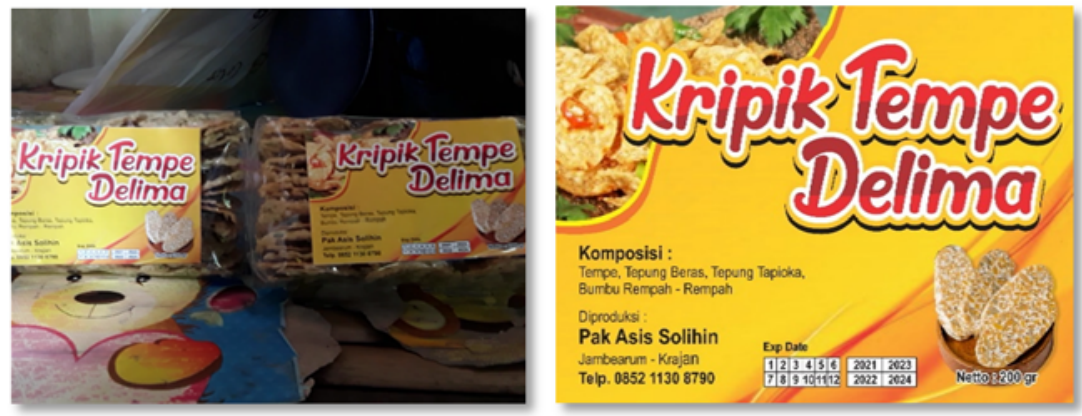

Gambar 14. Pengemasan keripik tempe yang sudah matang 
Pada tahapan ini, hasil keripik tempe yang sudah dingin kemudian baru dikemas kedalam plastik kemasan sesuai dengan standart. Pengemasan dalam kondisi dingin ini agar lebih tahan lama karena dapat meminimalisir uap panas yang masuk dalam kemasan ketika dikemas dalam kondisi panas. Setelah dikemas kedalam plastik kemudian dipress menggunakan sealer kemudian ditempel dengan brand yang telah dibuat yaitu "Keripik Tempe Delima" dari Desa Jambearum, Kecamatan Puger, Jember.

\section{Strategi pemasaran melalui media sosial sebagai bentuk digital marketing}

Pemasaran menjadi salah satu aktivitas bisnis yang dapat memberikan kontribusi dalam keberlanjutan dan perluasan suatu usaha. Aktivitas pemasaran ini juga menjadi salah satu manajemen pengelolaan suatu usaha yang sangat dinamis mengikuti kondisi pasar yang juga sangat dinamis. Di tengah perkembangan teknologi, sistem dan strategi pemasaran juga mengalami pergeseran dari model pemasaran konvensional menuju pemasaran digital. Model pemasaran konvensional yang dilakukan secara langsung dengan tatap muka antara penjual dan pembeli saat ini sudah tidak efisien untuk tujuan perluasan pasar. Dengan adanya model pemasaran digital ini membantu untuk meningkatkan efisiensi dalam perluasan jaringan pasar. Model pemasaran ini telah diintegrasikan dengan kekuatan teknologi informasi dalam aktivitasnya (Arifin et al., 2019). Kemajuan teknologi memiliki andil besar dalam keputusan pemasaran. Pesatnya perkembangan teknologi memaksa sistem pemasaran untuk melakukan peralihan ke digital secara online. Ini diharapkan dapat lebih prospektif dalam menjangkau konsumen dengan informasi lebih detail baik secara kualitas produk yang dipasarkan, harga, dan lainnya. Dalam studi yang dilakukan oleh Wardhana (2015) menemukan hasil bahwa digital marketing dapat mendorong keunggulan bersaing dalam memasarkan produk suatu usaha hingga mencapai $78 \%$. Hasil ini mengkonfirmasi bahwa pergeseran sistem pemasaran ke arah digital terlihat lebih efektif dan efisien dalam memasarkan produk dan menjangkau konsumen di segmen pasar digital. Pada kasus pemasaran keripik tempe di Desa Jambearum, Kecamatan Puger, Kabupaten Jember ini dilakukan upaya digital marketing melalui pembuatan media sosial Facebook. Media sosial Facebook dipilih sebagai alternatif pemasaran digital keripik tempe di Jambearum, sebab lingkungan masyarakat sekitar desa dan kecamatan mayoritas menggunakan Facebook sebagai media sosial untuk mengakses segala informasi. Sehingga upaya ini diharapkan dapat membantu memasarkan produk keripik tempe dengan jangkauan yang lebih luas melalui akun Facebook. Pada akun pemasaran di Facebook ini akan diunggah secara detail proses pembuatan, pengolahan, dan pengemasan keripik tempe sehingga konsumen nantinya dapat melihat bagaimana proses pembuatan yang higienis dan berkualitas dan diharapkan dapat menarik minat konsumen untuk membeli produk ini.

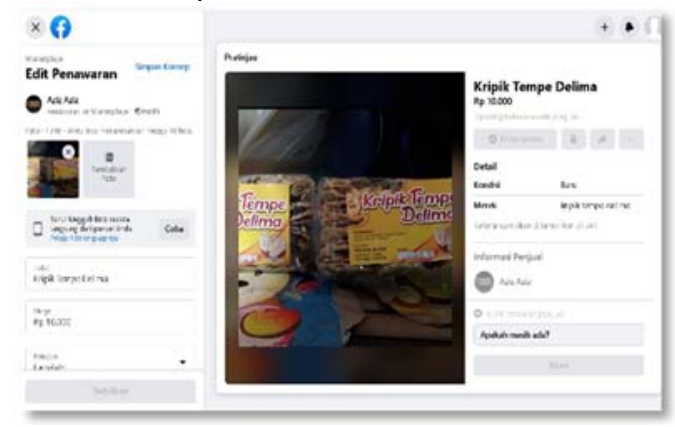

Gambar 15. Pembuatan akun media sosial Facebook 
ABDIMAS: Jurnal Pengabdian Masyarakat Universitas Merdeka Malang Volume 6, No. 3, August 2021: 372-383

Dampak positif yang diperoleh mitra dalam hal ini pelaku usaha tempe dengan adanya inovasi produk "Kripik Tempe Delima" diharapkan dapat meningkatkan pendapatan rumah tangga pelaku usaha. Berbekal teknik pengolahan keripik tempe yang disertai dengan variasi rasa, packaging, dan brand yang dicantumkan dalam produk akan menarik lebih banyak konsumen. Selain itu, pengenalan pemasaran digital yang dilakukan oleh tim melalui pemuatan media social Facebook dapat memperluas jaringan pemasaran sehingga pasar dapat diakses lebih mudah dan lebih luas lagi. Ini juga diharapkan dapat berdampak dan berjalan secara berkelanjutan agar usaha keripik tempe ini tetap eksis dan semakin besar.

\section{SIMPULAN DAN SARAN}

Hasil produksi tempe perlu mendapat perhatian khusus sehingga dapat dilakukan inovasi dan diversifikasi produk agar tempe tidak hanya sebatas menjadi bahan lauk pauk, namun juga sebagai produk makanan yang memiliki nilai tambah tinggi. Pembuatan keripik tempe ini diharapkan mampu memberikan peningkatan nilai tambah karena keripik tempe dapat dijadikan branding lokal seperti dapat dijadikan sebagai bahan cemilan dan oleh-oleh khas yang memiliki nilai jual lebih tinggi. Hal ini juga dapat berdampak pada peningkatan pendapatan pada produsen tempe ketika dapat berinovasi dengan baik untuk meningkatkan nilai jual produk keripik tempe ini. Hasil yang telah dicapai ditunjukkan dengan adanya beberapa permintaan pasar untuk keripik tempe "Delima" baik di pasar yang berada disekitar desa, maupun di luar desa dan kecamatan. Jangkauan pasar yang semakin luas ini juga sebagai dampak dari pemasaran digital melalui Facebook sehingga permintaan dapat menembus dari luar wilayah. Kebanyakan "Kripik Tempe Delima" dijadikan sebagai oleh-oleh khas desa maupun daerah dan cemilan sehari-hari.

Untuk pemahaman lebih jauh, maka diperlukan sosialisasi yang lebih optimal terkait dengan pemanfaatan tempe untuk menciptakan produk yang lebih inovatif dan memiliki nilai jual tinggi. Selain itu, upaya ini juga untuk mengasah dan menggali potensi serta kreativitas masyarakat untuk lebih siap dan tanggap dalam menghadapi perubahan permintaan dan selera pasar melalui inovasi-inovasi produk mereka khususnya tempe. Diperlukan juga sinergi dan dukungan antara pemerintah dan masyarakat agar dapat mencapai pengelolaan yang baik, sebab produksi ini juga harus didukung dengan pemasaran, pengemasan agar dapat dicapai keberlanjutan produk ini.

\section{DAFTAR PUSTAKA}

Adamu, N., Zubairu, I. K., Ibrahim, Y. M., \& Ibrahim, A. M. (2011). Evaluating the impact of product diversification on financial performance of selected Nigerian construction firms. Journal of construction in developing countries, 16(2), 91-114.

Arifin, B., Muzakki, A., \& Kurniawan, M. W. (2019). Konsep digital marketing berbasis SEO (Search Engine Optimization) dalam strategi pemasaran. Ekombis Sains: Jurnal Ekonomi, Keuangan Dan Bisnis, 4(2), 87-94. https://doi.org/10.24967/ekombis.v4i2.474 


\section{Pemanfaatan Bio-Economy dari Glycine Max dan Digital Marketing bagi Pengrajin Tempe \\ Siti Komariyah, Lilis Yuliati, Riniati Riniati}

Badan Pusat Statistik (BPS). (2017). Kabupaten Jember Dalam Angka 2017. Badan Pusat Statistik Kabupaten Jember. https://jemberkab.bps.go.id

Febrini, I. Y., Widowati, R., \& Anwar, M. (2019). Pengaruh experiential marketing terhadap kepuasan konsumen dan minat beli ulang di Warung Kopi Klotok, Kaliurang, Yogyakarta. Jurnal Manajemen Bisnis, 10(1), 35-54. https://doi.org/10.18196/mb.10167

Gregorius, H. (2010). Linking diversity and differentiation. Diversity, 2(3), 370-94. https://doi.org/10.3390/d2030370

Jayathilake, H. M. T. M. (2018). Product diversification strategies: A review of managerial skills for firm performance. International Journal of Advancements in Research and Technology, 7(7), 90-100. https://doi.org/10.14299/ijoart.07.07.004

Kotler, P., \& Keller, K. L. (2012). Marketing Management 14th Edition. New Jersey: Prentice Hall.

Kurniawati, E. T. (2016). IbM kripik tempe. Studi Kasus Inovasi Ekonomi, 1(1). https://doi.org/10.22219/skie.v1i1.4452

Oentoro, D. (2010). Manajemen Pemasaran Modern. Yogyakarta: LaksBang.

Scur, G., \& De Queiroz, R. P. (2017). The impact of diversification in the operations strategy of capital goods companies. Gestao e Producao, 24(2), 206-20.

Soemali, R. N., \& Dharmayanti, D. (2015). Pengaruh product innovation, product quality dan brand image terhadap customer loyalty dengan competitive advantage sebagai variabel intervening di PT. Wijaya Indonesia Makmur Bicycle Industries Gresik. Jurnal Manajemen Pemasaran Petra, 3(1), 1-10.

Suharno, S., \& Saraswati, E. (2019). Meningkatkan nilai tambah produk tahu melalui diversifikasi produk menjadi Tahu Baxo di Desa Kalikabong, Kecamatan Kalimanah, Kabupaten Purbalingga. Dinamika Journal: Pengabdian Masyarakat, 1(2), 6-11. https://doi.org/10.20884/1.dj.2019.1.2.887

Tarida, Y. (2012). Strategi diferensiasi produk, diversifikasi produk, harga jual dan kaitannya terhadap penjualan pada industri kerajinan rotan di Kota Palembang. Jurnal Ekonomi Pembangunan, 10(2), 124-142. https://doi.org/10.29259/jep.v10i2.4908

Uula, P. M., Indah, P. N., \& Abidin, Z. (2019). Strategi pemasaran digital pada produk tempe, Kota Surabaya. Agridevina: Berkala Ilmiah Agribisnis, 8(2), 127-134. https://doi.org/10.33005/adv.v8i2.1843

Wardhana, A. (2015). Strategi Digital Marketing dan Implikasinya pada Keunggulan Bersaing UKM di Indonesia. Conference: Seminar Keuangan dan Bisnis IV UPI 2015, Bandung. 